(c) (1)

\title{
Elazığ yöresinde yetişen badem ağaçlarının (Prunus amygdalus Batsch) yetişme ortamı özelliklerinin belirlenmesi
}

\author{
Determination of the site condition for the almond trees (Prunus amygdalus Batsch) growing in the Elazig region
}

\author{
Tuğçe Dilşad AKGÜN¹ (D), Mustafa TÜFEKçioĞLU² iD, Mehmet KÜçüK² iD \\ ${ }^{1}$ Elazığ Orman İşletme Müdürlüğü Elazığ, Türkiye \\ ${ }^{2}$ Artvin Çoruh Üniversitesi Orman Fakültesi Orman Mühendisliği Bölümü Artvin, Türkiye
}

Eser Bilgisi/Article Info
Araştırma makalesi / Research article
DOI: 10.17474/artvinofd.485113
Sorumlu yazar/Corresponding author
Mustafa TÜFEKÇiOĞLU
e-mail: mtufekcioglu61@artvin.edu.tr
Geliş tarihi / Received
19.11.2018
Düzeltme tarihi / Received in revised form
08.02.2019
Elektronik erişim / Online available
15.02.2019
Anahtar kelimeler:
Badem ağacl
Tekstür
Kireç
Organik madde
Makro ve mikro besin elementleri
Keywords:
Almond tree
Texture
Lime
Organic matter
Macro and micro nutrient

\begin{abstract}
Özet
Elazığ ilinde son yıllarda badem ağaçlandırmalarına oldukça önem verilmiş ve yaygınlaştırılmıştır. Bu önem bademin sınır ağacı olarak kullanımı ve tohumdan yetiştirilebilmesinin yanı sıra ıslah çalışmalarının yapılarak bahçeler kuruıması, bakımının ve budamasının yapılması ile ürün kalitesinin ve neticesinde ekonomik girdisinin artırılması ile daha da artmaktadır. Bu bağlamda çalışmada Elazığ ilinde geniş bir yayılışa sahip olan badem ağacının yetişme ortamı özelliklerinin (toprak, iklim ve yükselti) belirlenmesi hedeflenmiştir. Çalışma bademin iyi gelişim gösterdiği doğal, emekle yetiştirilen ve ağacının yaygın yayııış gösterdiği Elazığ ilinin 5 farklı yöresinde (Elazığ Merkez, Keban, Sivrice, Ağın ve Baskil) toprak örneklemesi yapılarak gerçekleştirilmiştir. Bu toprakların fiziksel ve kimyasal özelliklerine ait bulgular toprak verimliliğinin sınıflandıııldığı "sınır değerleri çizelgesine" göre değerlendirilmiştir. Toprak örnekleri üzerinde tekstür, $\mathrm{pH}$, kireç, tuz, organik madde, makro ( $\mathrm{P}$, $\mathrm{K}, \mathrm{Ca}, \mathrm{Mg}$ ) ve mikro besin elementleri ( $\mathrm{Fe}, \mathrm{Cu}, \mathrm{Zn}, \mathrm{Mn}$ ) analizleri yapılmıştır. Badem ağacı yetiştiriciliği açısından değerlendirildiğinde Elazığ ili yöresi topraklarının tekstür ve tuzluluk açısından her hangi bir kısıtlayıcı etki oluşturmadığı özellikle tekstür bakımından geniş bir değişkenliğe sahip olduğu ortaya çıkmıştır. Diğer taraftan toprak reaksiyonunun hafif alkaliliği, kireç miktarının fazlalığı ve organik madde içeriğinin azlığı göze çarpan önemli hususlar olarak belirlenmiştir. Topraklara daha fazla organik madde ilavesi ile alkaliliğin ve kireç'in azaltılmasına çalışılmalıdır. Besin elementleri değerlendirildiğinde, bütün yöre topraklarının mangan yönünden fakir olduğu, yarayışlı potasyum, bakır, çinko ve demir yönünden yeterli olduğu belirlenmiştir. Yarayışı fosfor, kalsiyum ve magnezyum yönünden ise zengin olduğu tespit edilmiştir. Gübre takviyesiyle besin elementi noksanlığı giderilebilir.
\end{abstract}

\begin{abstract}
The importance of almond plantation in and around the Elazig regions is a growing interest in recent years. The use of almond as a borderline tree and the cultivation of its seeds are important characteristics of this tree. However, the aim of increasing the quality and the economic benefit of growing almond trees can be achieved by the rehabilitation works including construction of new gardens, maintenance and pruning as well. In this context, the main goal of the study was to determine the site condition (soil, climate, and elevation) of the almond tree growing in five different Elazig regions including Elazig center, Keban, Sivrice, Agin, and Baskil where the almond tree is widely distributed. The specific objective of the study was to assess the physical and chemical contents of the soil samples from the regions of Elazıg according to soil fertility classification by the "limit value table". In that so, the soil samples were analyzed for texture, $\mathrm{pH}$, lime, salinity, organic matter, macro ( $\mathrm{P}, \mathrm{K}, \mathrm{Ca}, \mathrm{Mg}$ ) and micronutrient contents ( $\mathrm{Fe}, \mathrm{Cu}, \mathrm{Zn}, \mathrm{Mn})$. In terms of the growth of Almond tree across the Elazı $\breve{g}$ regions, soil texture and salinity conditions showed no restrictive effects. Indeed, soil samples showed wide variability in terms of texture. On the other hand, the slight alkalinity of soil reaction, high lime content, and insufficient organic matter contents were found as the important drawback for the collected soil samples from the regions. It should be tried to reduce the alkalinity and lime content of the soils by adding more organic matter to it. Results for the nutrient contents showed that the soil samples were poor in manganese, sufficient in available potassium, iron, zinc, and copper, and rich in available phosphorus, calcium and magnesium. Nutrient deficiency can be eliminated with mineral fertilizer supplementation.
\end{abstract}




\section{Giriş}

Türkiye, coğrafi konumu ve sahip olduğu çok farklı iklim tipleri nedeniyle çoğu meyve türlerinin gen merkezi ve doğal yayılma alanı durumundadır. Bu durumun Anadolu'da yüzlerce yıldan beri ekolojik istekleri farklı, çok zengin bitki tür ve çeşitliliğinin ortaya çıkmasına neden olmuştur. Anadolu, birçok meyve türünün olduğu gibi bademin de anavatanı ve doğal yayılma alanlarından birisidir (Özbek, 1971). Badem (Prunus dulcis (Mill.) D.A. Webb. syn. Prunus amygdalus Batsch, and Prunus communis (L.)), Rosaceae familyasının Prunus cinsi içeresinde olup (Phychorraphis 1977; Rugini ve Monastra, 2003) yaklaşık 40 türü vardır ve bunlardan 12'si Türkiye de mevcuttur. (Kester and Gradziel 1996; Soylu 2003). Badem sert çekirdekli meyveler grubuna girmekte olup ticari anlamda meyvesi için yetiştirilen bir türdür (Ülkemen 1973; Özbek 1978). İç badem kurutulmuş olarak bütün bir yıl boyunca tüketilebilmektedir. Ülkemizde kavrulmadan veya tuzlutuzsuz kavrularak çerezlik olarak tüketilmektedir. Pasta, şekerleme ve çikolata saniyesinde de çok geniş kullanım alanına sahiptir. Bademlerden üretilen yağın hammadde olarak en çok kullanım alanlarından biriside kimya ve boya sanayisidir. Ayrıca bazı ülkelerde sert kabuklar sunta üretimi ve yakacak olarak kullanılırken, yeşil kabuklarda hayvan yemi olarak değerlendirilir (Özçağıran vd. 2005). Bademin ekonomik anlamda sağladığı katkının yansıra, ağaçlandırma ve erozyon kontrolü çalışmaları açısından da değerlendirilip yetiştirilebilmesi ülkemiz açısından çok önemlidir.

Türkiye de Doğu Karadeniz bölgesini kıyı ve çok yüksek yayları hariç diğer bütün bölgelerde badem yetişebilmektedir. Badem yetiştiriciliğinin en fazla olduğu bölgelerin başında Ege Bölgesi, takiben Akdeniz, Güney Doğu Anadolu, i̧̧̇ Anadolu ve Marmara Bölgeleri gelmektedir. Badem üretimindeki en büyük pay $\% 61^{\prime}$ lik oranla Ege ve Akdeniz bölgelerine aittir (URL 1). Uygun iklimsel yapıya sahip olan Güney Doğu Anadolu Bölgesi de badem üretiminin ekonomik olarak karlı yapılabileceği potansiyel bölgelerimiz arasında yer almaktadır (Şimşek ve Gülsoy 2017). Ekonomik açıdan değerlendirildiğinde bademin gelir elde etme amacıyla yetiştirilemediği alanlar özellikle ilkbahar geç donlarının sık yaşandığı bölgelerdir. Badem yetiştiriciliğinin en önemli problemlerinden biri olan bu sorun ekolojik koşullara uygun, geç çiçek açan genotiplerin (çeşit, klon, tip ve ekotip) Islah edilmesiyle çözüme kavuşturulabilir (Akçalı ve Uzun 2016). Yüksek kuraklık direncine sahip olmasına rağmen, badem ağacı yağışın 300 mm'nin altında olan bölgelerde özellikle ağaçlandırma amacıyla nadiren de sınırlı gelir kaynağı olarak yetiştirilebilir (Anonim 1981). Fazla verimli olmayan ve birçok kültür bitkisinin yetişemeyeceği arazilerde kolaylıkla yetişebilen ve verimliliğini koruyan bir meyve olan badem, bu gibi alanların ağaçlandırılmasında kullanılan önemli bir türdür (Naçan 1986). Diğer sert kabuklu meyvelere göre badem, kanaatkâr bitki olması, uyum kabiliyetinin yüksekliği, meyvesinin beslenme değerinin yüksek olması ve erken verime yatması sebebiyle uygun ekolojik şartlardaki yetiştiriciliğine olan taleplerde her geçen gün artmaktadır. Dünyadaki badem üretimindeki artışa paralel olarak Türkiye dede badem üretim miktarı son yıllarda artışa geçmiştir. Nitekim on yıllık ortalama badem üretimi 1988-1997 yıllarında 43500 ton, 19982007 yıllarında 42604 ton olarak gerçekleşirken, bu miktar son on yılda (2008-2017) 72420 tona çıkmıştır (URL 2). Bu artışta ekonomik kazanç amaçlı yeni badem bahçelerinin özel kişilikler tarafından kurulmasının yansıra Orman Genel Müdürlüğünün kırsalda yapmış olduğu erozyon kontrol ve rehabilitasyon amaçlı ağaçlandırma faaliyetlerinin büyük katkısı olduğu düşünülmektedir. Her iki durumda da badem ürettirmedeki artış beraberinde ilgili yöre halkının gelir ve refah seviyesini artırarak kırsal kalkınmaya katkı sağlayacaktır. Ayrıca yeni bahçe tesisi için seçilen ithal badem çeşitlerinin bu artan üretim miktarında etkisi büyüktür. Fakat ayrıca belirtmek gerekir ki yapılan ıslah çalışmalarında yerli badem türlerinin de değerlendirilip çeşitlendirilmesine önem verilmesi gerekmektedir (Eldoğan vd. 2014)

Badem ekonomik değeri çok yüksek olan sert kabuklu bir meyve olması, dış ve iç pazar talebindeki artış ve ülkemizin bu pazardaki payının arttırılması için yetiştiriciliğinin desteklenmesi ve üretiminin artırılması önem arz etmektedir (Eldoğan vd. 2014). Nitekim, ülkemizde son 15-20 yıl içeresinde badem üretimini artırıcı birçok çalışma yapılmıştır (Akçay ve Tosun 2005; 
Şimşek vd. 2010; Alkan ve Seferoğlu 2014; Gülsoy ve Balta 2014; Gülsoy vd. 2016; Akçalı ve Uzun 2016). Fakat bu çalışmalar genellikle bademin fenolojik ve morfolojik özelliklerine yoğunlaşmaktadır. Seleksiyon yolu ile bademin ıslah çalışmalarının yapılması ve neticesinde üretiminin aratılması büyük önem arz etmekle birlikte badem yetiştiriciliğinin yapıldığı bu alanların toprak istek ve özelliklerin (fiziksel ve kimyasal) araştırıması, uygun ekolojik koşulların belirlenmesine ve neticesinde üretiminin daha da çok artırılmasına katkı sağlayacaktır. Bu bağlamda çalışmada bademin doğal yayılış gösterdiği Elazığ ilinin beş farklı yöresindeki yetişme ortamı özelliklerinin (tekstür, kireç, organik madde, toprak reaksiyonu, makro ve mikro besin elementleri) belirlenmesi ve toprak verimliliğinin "verimlilik sınır değerlerine" göre değerlendirilmesi amaçlanmıştır. Yörelerden alınan toprak örnekleri ve arazi incelemelerinde elde edilen sonuçlar bademin genel olarak hangi toprak, iklimsel ve topografik koşullara uyum sağlayıp yetiştirilebileceğine ışık tutacaktır.

\section{MATERYAL VE YÖNTEM}

\section{Çalışma Alanı ve Deneme Deseni}

$\mathrm{Bu}$ çalışma için toprak numuneleri bademin doğal ve/veya emekle yetiştirildiği, yoğun yayılış gösterdiği Elazığ ilinin beş farklı yöresinden (Elazığ Merkez, Sivrice, Keban, Baskil ve Ağın) en az üç tekrarlı toprak profil örneklemesi şeklinde yapılmıştır (Şekil 1). Bu yörelerdeki 16 farklı mevkiden seçilen örnekleme alanlarının yükselti, eğim, bakı ve koordinat bilgileri aşağıda Çizelge 1 de detaylı olarak verilmiştir. Toprak profillerinin açılmış olduğu mevkilerin deniz seviyesinden yükselti değerleri $860 \mathrm{~m}$ ile $1690 \mathrm{~m}$ arasında değişim göstermektedir (Çizelge 1). Bu mevkilerinin eğim yüzdeleri ise $\% 2$ ve $\% 20$ arasında değişmektedir. Genel yapı açısından değerlendirildiğinde ise profillerin açıldığı örnek alanların büyük çoğunluğu \%2-5 gibi düşük eğim aralığında yer almaktadır (Çizelge 1). Genel olarak değerlendirildiğinde Elazığ çevresi jeolojik açıdan farklı yaştaki magmatik, metamorfik, volkanik ve tortul kayaçları içermektedir (URL 3).

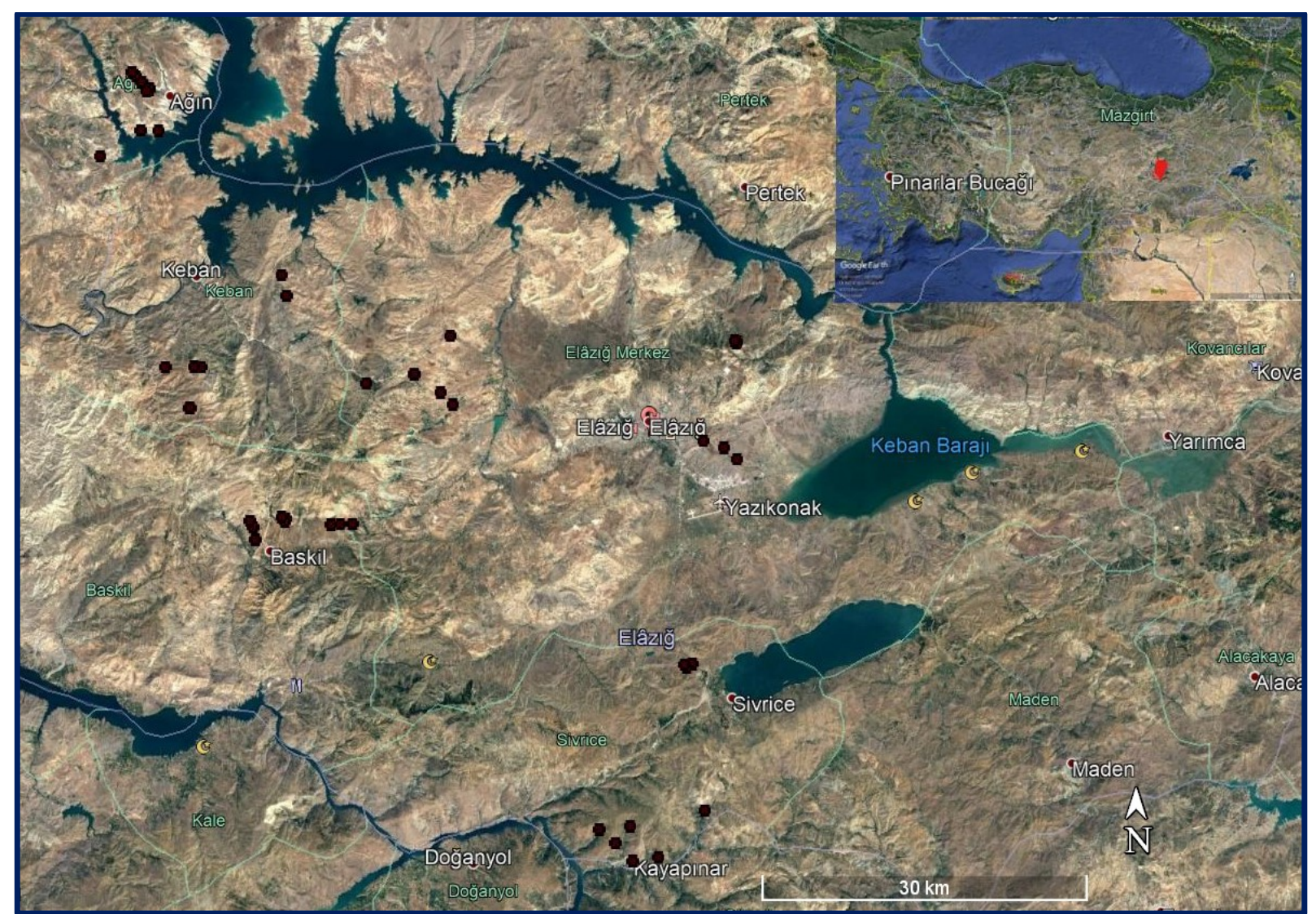

Şekil 1. Çalışmanın yapııdığı Elazığ ili ve yöreleri; Elazığ merkez, Sivrice, Baskil, Keban ve Ağın yörelerinde açılan toprak profil noktaları. 
Çizelge 1.Toprak örneklemesinin yapıldığı toplamda $48(16 \times 3)$ deneme alanına (mevki) ait genel bilgiler; toprak örneklerinin alınmış olduğu mevki, bakı, rakım, eğim derecesi ve koordinat bilgileri.

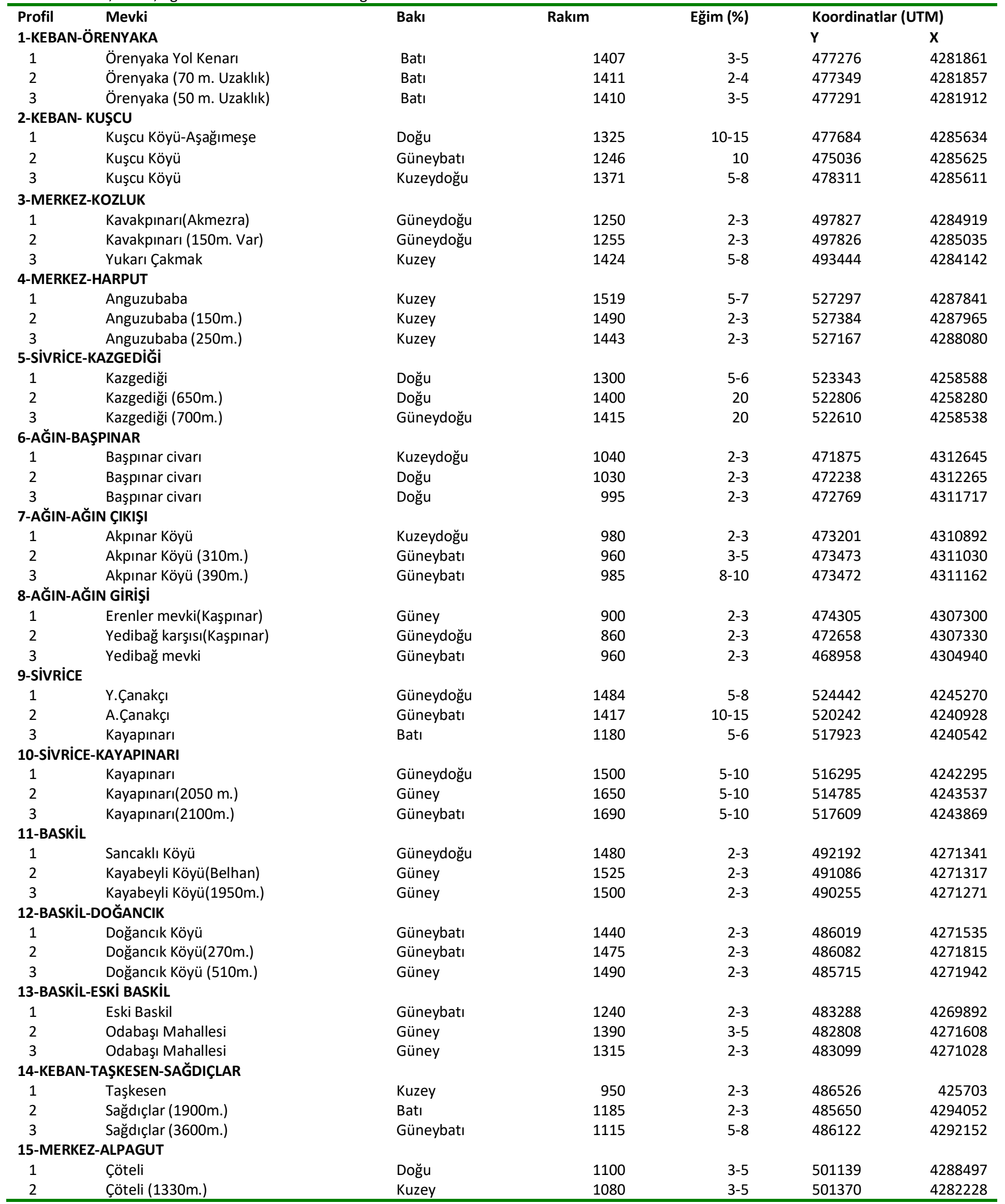




\begin{tabular}{cllrrr}
\hline 3 & Çemişgezek Yol Ayrımı & Doğu & 1125 & $3-5$ & 500242 \\
16-MERKEZ & & & & 4283343 \\
1 & Beyyurdu Mah. & Batı & 1180 & $2-3$ & 524361 \\
2 & Beyyurdu Mah. & Kuzeydoğu & 1080 & $4-5$ & 526249 \\
3 & Yurtbaşı & Doğu & 980 & 4278937 \\
\hline
\end{tabular}

Not: Merkez de 4 farklı alanda (Kozluk, Harput, Alpagut ve Merkez), diğer ilçelerde/yörelerde (Keban, Sivrice, Ağın ve Baskil) ise 3 farklı alanda olmak üzere toplamda 16 alanda toprak profilleri açılmıştır. Ayrıca her bir alandaki tekrar amaçlı açılan 3 ayrı $(1,2$ ve 3$)$ toprak profilinden örneklemeler yapılmıştır.

Elazığ ili için yapılan farkıı iklim sınıflandırmalarına göre çalışma alanlarının genel olarak yarı kurak ve yarı kurakyarı nemli iklim tipine sahip olduğu görülmektedir. Bu sınıflandırmalardan Erinç (1984) yağış etkinlik indeksine göre yarı kurak ve yarı nemli, De Martonne'e (1942) göre yarı kurak ve yarı kurak-nemli arası, Thornthwait'e (1948) göre ise yarı kurak ve yarı kurak-az nemli olduğu tespit edilmiştir. Bu sınıflandırma tiplerinin ürettiği haritalar incelendiğine Elazığ yöresinin düşük rakımlı alanları yarı kurak, yüksek rakımlı alanları ise yarı nemli iklim sınıfında olduğu görülmektedir (URL 4). Yazlar sıcak ve kurak, kışlar ise soğuk ve sert geçen bölge ve çevresine ait uzun yıllar (1950-2014) iklim verileri aşağıda Çizelge 2 'de verilmiştir.

Çizelge 2'ye göre bölgede uzun yıllar içinde gerçekleşen en yüksek sıcaklık $38.6^{\circ} \mathrm{C}$ ile Haziran ve en düşük sıcaklık ise $-22.6{ }^{\circ} \mathrm{C}$ ile Ocak ve Aralık aylarına görülmüştür. Ortalama değerlere bakıldığında en yüksek sıcaklık Temmuz ayında $34.2^{\circ} \mathrm{C}$ ve ortalama en düşük sıcaklık ise Ocak ayında $-4.1^{\circ} \mathrm{C}$ olarak gerçekleşmiştir. Ortalama yıllık yağış miktarı ise $408.7 \mathrm{~kg} \mathrm{~m}^{-2}$ olarak gerçekleşmiştir. Özellikle Nisan ve Ekim dönemlerinde badem için önemli olan geç ve erken donlar görülmektedir. Bunun yanında bölge, bademin olgunlaşma ve kavlanma döneminde gerekli sıcak ve kurak bir yaz periyoduna sahiptir. Bu dönemdeki ortalama sıcaklıklar Haziran için 22.9, Temmuz için 27.3 ve Ağustos için $26.9{ }^{\circ} \mathrm{C}$ olarak gerçekleşmiştir. Araştırmanın yapıldığı Elazığ yöresi genel olarak kışları soğuk, yazları sıcak olmakla birlikte, en yüksek aylık toplam yağışlar Ekim-Mayıs ayları arasında gerçekleşmektedir (Çizelge 2).

Çizelge 2. Elazığ iline ait uzun yıllar (1950-2014) iklim verileri (URL 3).

Uzun Yıllar İçinde Gerçekleşen Ortalama Değerler (1950-2014)

ELAZIĞ

Ortalama sıcaklık $\left({ }^{\circ} \mathrm{C}\right)$

Ortalama en yüksek sıcaklık $\left({ }^{\circ} \mathrm{C}\right)$

Ortalama en düşük sıcaklık $\left({ }^{\circ} \mathrm{C}\right)$

Ortalama güneşlenme süresi (saat)

Ortalama yağışlı gün sayısı

Aylık toplam yağış $\left(\mathrm{kg} / \mathrm{m}^{2}\right)$

En yüksek sıcaklık $\left({ }^{\circ} \mathrm{C}\right)$

En düşük sıcaklık $\left({ }^{\circ} \mathrm{C}\right)$

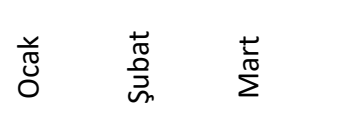

$-0.9$

$2.8-4.9$

$-4.1-3.2$

$2.4 \quad 3.5$

$11.9 \quad 11.7$

$40.2 \quad 41.6$

$12.4 \quad 17.4$

$-22.6-21.4$

\section{$\underset{\substack{0 \\ \frac{0}{2}}}{\stackrel{.}{2}}$}

5.7

$11.0 \quad 17.8$

1.0

5.1

12.3

52.7

26.4

$-17.0$

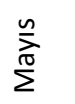

$\frac{\frac{1}{10}}{\frac{1}{N}}$

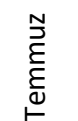

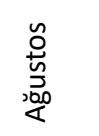

$17.2 \quad 22.9$

23.5

10.7

$\begin{array}{lll}9.6 & 11.2 & 12.0\end{array}$

$\begin{array}{ccc}11.1 & 4.4 & 1.1\end{array}$

$\begin{array}{lll}54.3 & 13.3 \quad 1.9\end{array}$

$34.4 \quad 38.6$

$0.0 \quad 4.0$
高

$21.7 \quad 14.6$

$\begin{array}{ll}21.7 & 14.6 \\ 29.3 & 21.6\end{array}$

$$
\begin{array}{ll}
14.4 & 8.9
\end{array}
$$

$9.4 \quad 7.0$

$\begin{array}{ll}9.4 & 7.0 \\ 2.2 & 7.0\end{array}$

$\begin{array}{ll}8.2 & 40.0 \\ 37.8 & 32.1\end{array}$

$42.2 \quad 41.4$

6.710

$\begin{array}{ll}1.0 & -2.2\end{array}$

\begin{tabular}{|c|c|c|}
\hline $\begin{array}{l}\underline{\xi} \\
\bar{w} \\
\underline{\tilde{x}}\end{array}$ & 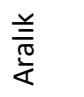 & $\frac{\text { 兰 }}{\overline{\bar{\nu}}}$ \\
\hline 7.2 & 1.6 & 13.1 \\
\hline 12.5 & 5.3 & 18.9 \\
\hline 3.0 & -1.3 & 7.5 \\
\hline 4.4 & 2.2 & 84.4 \\
\hline 9.3 & 11.8 & 96.2 \\
\hline 46.4 & 44.0 & 408 \\
\hline 24.3 & 19.6 & 29.9 \\
\hline-15.2 & -22.6 & -7.2 \\
\hline
\end{tabular}

\section{Toprak Profillerinin Açılması ve Örnekleme}

Bu çalışmada bademin yetişme ortamı özelliklerini daha detaylı bir şekilde karakterize edebilmek için 16 farklı alanda 3 tekrarlı olacak şekilde toplamda 48 adet toprak profili açılmıştır. Açılan her bir toprak profilinden 0-30 $\mathrm{cm}, 31-60 \mathrm{~cm}$ ve $61-90 \mathrm{~cm}$ derinlik kademelerinden toplamda $144(16 \times 3 \times 3)$ adet toprak örneği alınmıştır. Profil çukurunun eni 75-100 cm, boyu 100-150 cm kadar açılmıştır. Derinliği ise $90 \mathrm{~cm}$ 'den az olmamak üzere kazılmıştır. Toprak yüzeyinin üzerindeki ölü ve diri örtünün doğal durumunun bozulmamasına dikkat edilerek 3 derinlik kademesinden (0-30, 30-60 ve 60-90 $\mathrm{cm})$ analizlere yetecek ölçüde toprak numunesi naylon poşetlere konarak analiz için laboratuvara getirilmiştir.

\section{Toprak Analizleri}

Toprak örnekleri laboratuvardaki kurutma alanında kâğıtlar üzerine serilmiş ve hava kurusu hale gelinceye 
kadar kurutulmuştur. Kurutma sonrası toprak örnekleri, porselen havanlarda usulüne uygun olarak öğütülmüştür. Daha sonra $2 \mathrm{~mm}$ 'lik elekten geçirilen örnekler polietilen torbalara konularak analize hazır hale getirilmiştir (Irmak 1954; Altun 1995). Analize hazır hale getirilmiş (2 $\mathrm{mm}$ 'den ince kısım) toprak örneklerinin Bouyoucos'un (1951) hidrometre yöntemine göre mekanik analize tabi tutulmasıyla kum, silt ve kil oranları bulunmuş ve uluslararası tekstür üçgenine (E.C. Tommerup'a) göre tekstür sınıfları belirlenmiştir (Gülçur 1974). Toprak örneklerinin reaksiyonları (pH), İnolab pH level I pH metresi yardımıyla cam elektrot yöntemiyle belirlenmiş̧ir. Aktüel asitlik için yapılan analiz 1/2,5 oranında arı suda gerçekleştirilmiştir (Gülçur 1974). Topraktaki organik madde, modifiye edilmiş Walkley Black ıslak yakma yöntemine göre belirlenmiştir (Gülcur 1974, Kaçar 2009). Toprak örneklerinin $\mathrm{CaCO}_{3}$ miktarları (\%) Scheibler kalsimetresi ile volumetrik olarak tayin edilmiştir (Çağlar 1949). Analiz sonuçları Aereboe ve Falke'ye göre sınıflandırılmıştır (Evliya 1960). Saf su ile doyurulmuş toprak macununda elektrik direnci Beckman Conductivity Bridge aleti ile ölçülmüştür. Ölçülen elektrik direnci (ohm) toprak bünyesi ve toprak macunu sıcaklığı $\left({ }^{\circ} \mathrm{F}\right)$ değerleri dikkate alınarak redüksiyon monogramına uygulanmıştır. Bu şekilde toprak örneklerinin eriyebilir toplam tuz miktarları \% olarak saptanmıştır (USDA-NRCS 2011). Toprak örneklerinin faydalı fosfor (P) miktarları Bingham (1949), metoduna göre kolorimetrik olarak Eppendorf kolorimetresinde tayin edilmiş ve sonuçlar mg $\mathrm{kg}^{-1}$ olarak hesaplanmıştır. Toprakların faydalı $\mathrm{K}, \mathrm{Ca}, \mathrm{Mg}$ değerleri $1 \mathrm{~N}$ Amonyum asetat $\left(\mathrm{NH}_{4} \mathrm{OAC}\right)$ yöntemine göre $\mathrm{pH}$ değeri 7 olan $1 \mathrm{~N}$ Amonyum asetat ile çalkalanarak elde edilen süzüklerde; $\mathrm{K}$, $\mathrm{Ca}$, değerleri Flame fotometrede, $\mathrm{Mg}$ değerleri ise Atomik Absorbsiyon Spektrofotometresinde tayin edilmiştir (Chapman ve Pratt 1961). Toprakların Fe, Cu, Zn ve Mn miktarları DTPA (diethylene triamine penta acetic acid tampon çözeltisi) metoduna göre elde edilen süzüklerden Atomik Absorbsiyon Spektrofotometresinde okunup, $\mathrm{mg} \mathrm{kg}^{-1}$ olarak hesaplanmıştır (Linsday ve Norvell 1978).

\section{Toprakların Fiziksel ve Kimyasal Özelliklerine Ait Sınır Değerleri}

Meyve yetiştiriciliği açısından toprakların verimliliği Çizelge 3'de değerlendirilmiştir.

Çizelge 3. Toprak özellikleri ve toprağın makro ve mikro besin elementlerinin FAO (1990), Richards (1954), Ülgen ve Yurtsever (1974)'e göre belirlenen verimlilik analiz sonuçlarının değerlendirilmesinde kullanılan "sınır değerlerinin" sınıflandırılması.

\begin{tabular}{|c|c|c|c|c|c|}
\hline Besin Maddesi ve Yöntem & Çok Az & $A z$ & Yeterli & Fazla & Çok Fazla \\
\hline $\mathrm{P},\left(\mathrm{NaHCO}_{3}\right)\left(\mathrm{mg} \mathrm{kg}^{-1}\right)$ & $<2.5$ & $2.5-8.0$ & $8.0-25$ & $25-80$ & $>80$ \\
\hline $\mathrm{K}, \mathrm{CH}_{3} \mathrm{COONH}_{4}\left(\mathrm{mg} \mathrm{kg}^{-1}\right)$ & $<50$ & $50-109$ & $109-288$ & $288-998$ & $>998$ \\
\hline $\mathrm{Ca}, \mathrm{CH}_{3} \mathrm{COONH}_{4}\left(\mathrm{mg} \mathrm{kg}^{-1}\right)$ & $<238$ & $238-1150$ & $1150-3500$ & $3500-10000$ & $>10000$ \\
\hline $\mathrm{Mg}, \mathrm{CH}_{3} \mathrm{COONH}_{4}\left(\mathrm{mg} \mathrm{kg}^{-1}\right)$ & $<50$ & $50-160$ & $160-480$ & $480-1500$ & $>1500$ \\
\hline $\mathrm{Mn},(\mathrm{DTPA}) \mathrm{mg} \mathrm{kg^{-1 }}$ & $<4$ & $4-14$ & $14-50$ & $50-170$ & $>170$ \\
\hline Zn, (DTPA) mg kg-1 & 0.2 & $0.2-0.7$ & $0.7-2.4$ & $2.4-8.0$ & $>8.0$ \\
\hline \multirow[t]{2}{*}{$\mathrm{Cu}$, (DTPA) mg kg-1 } & $<0.2$ & $>0.2$ & & & \\
\hline & Az Kireçli & Kireçli & Orta Kireçli & Fazla Kireçli & Çok Fazla Kireçli \\
\hline \multirow[t]{2}{*}{ Kireç \% (Scheiber) } & $0-1$ & $1-5$ & $5-15$ & $15-25$ & $>25$ \\
\hline & Tuzsuz & Hafif tuzlu & Orta tuzlu & Çok tuzlu & \\
\hline \multirow[t]{2}{*}{ Tuz,\% } & $0-0.15$ & $0.15-0.35$ & $0.35-0.65$ & $>0.65$ & \\
\hline & Çok Az & $A z$ & Orta & İyi & Yüksek \\
\hline
\end{tabular}

\section{İstatistik Analizleri}

Elde edile veriler üzerinde SPSS 16.0 versiyonu kullanılarak istatistik analizler yapılmıştır. Yöreler arasındaki farklılığı belirlemek için tek yönlü varyans
(One way anova) analizi kullanılmıştır. Önemli farklılıkların $(p<0.05)$ hangi yöreler arasında olduğunu belirlemek için Duncan testi uygulanmıştır. Yapılan istatistiksel analizlerde üç ayrı toprak profil derinliğinin 
(0-30, 31-60 ve $61-90 \mathrm{~cm})$ ortalama değeri kullanılmıştır. Bu profil derinlikleri arasındaki farklılıklarının çok az düzeyde gerçekleşmesi yukarda ifade edilen ortalama değer kullanımını anlamlı ve uygun kılmıştır. Verimlilik "sınır değerleri" açısından farklııı̆ın olduğu durumlarda (potasyum ve organik madde için) ilgili parametrelerde ayrıca ifade edilen profil derinliklerine göre de tartışılmıştır.

\section{BULGULAR VE TARTIŞMA}

Sıcaklık badem yetiştiriciliğinde önemli bir faktördür. Meyve kalitesi ve gelişimini etkileyen en önemli faktörlerden biride düşük yaz sıcaklıklarıdır. Bademin düşük kış sıcaklıklarında da tomurcukların ve dalların zarar gördüğü gözlenmiştir. Kalın dallarda ve gövdedeki zararlar -23 dereceden sonra başlamaktadır. (Anonim 1981). Toprak istekleri bakımından seçiciliği fazla olmayan kanaatkâr bir tür olduğu ifade edilen badem; hafif, derin, süzek ve alüvyon topraklarda da iyi ürün verdiği ifade edilmektedir. Elazığ ilinin beş farklı yöresinde yapılan bu çalışma, genel olarak bademin bu alanlarda yükseltinin 800-1700 m arasında, eğimin \%2-5 arasında değiştiği mevkilerde doğal yayılış gösterdiğini ortaya koymuştur. Bölgeler bademin olgunlaşması için gerekli yaz sıcaklıklarına sahip olmakla birlikte, ilkbahar ve son baharda oluşan geç donlar meyve tutumunu dolayısı ile de ürün verimini etkilemektedir. Elazığ yöresinin düşük rakımlı kısımları yarı-kurak, yüksek rakımlı kısımları ise yarı nemli iklim sınıflandırması içeresinde yer almaktadır. Bu bağlamda düşük yükseltilerde yağışın yaklaşık $300-350 \mathrm{~mm}$ olduğu alanlarda badem yetiştiriciliğinden yeterli üretim ve verimi alabilme kısmide olsa gerçekleşmeyecektir. Bu özellikteki alanlarda badem yetiştiriciliğinin ticari amaçla yapılması arzulanan kazancı sağlamayacaktır. Genel olarak değerlendirdiğimizde ise Elazı̆ğ merkez ve dört farklı yöresi badem için uygun iklimsel koşullara ve topoğrafyaya sahip olduğu belirlenmiştir. Çalışma yörelerine ait toprak örneklerinin fiziksel ve kimyasal özelliklerine ait bulgular Çizelge 4'de verilmiştir. Farklıık anlam düzeyinin $p<0.05$ olarak değerlendirildiği bu çalışmada yöreler arasındaki farklılıklar silt, organik madde ve potasyum için anlamlı bulunmamıştır (Çizelge 4). Diğer bütün toprak parametreler için anlamlı farklııklar mevcuttur.

\section{Toprak Fiziksel ve Kimyasal Özellikleri}

\section{Tekstür}

Yöreler açısından ortalama kum değerleri \%35.5 (Ağın) ve \%51.0 (Keban) arasında değişim göstermiştir (Çizelge 4). Tüm yörelerin ortalama kum miktarı \%45.7 olarak hesaplanmıştır. Çalışma yörelerindeki tüm toprak örneklerinin (toprak profillerinin; 0-90 cm) ortalama kum değerleri incelendiğinde en düşük kum miktarı \%21.4 ile Baskil yöresinde belirlenirken en yüksek değer ise Keban yöresinde $(\% 70,0)$ belirlenmiştir. Keban ve Sivrice yörelerindeki ortalama kum yüzdeleri farklı olarak Ağın yöresine göre anlamlı düzeyde yüksek çıkmıştır (Çizelge 4). Kil değerleri ise \%27.6 (Keban) ve \%42.3 (Ağın) arasında değişim göstermiştir. Tüm yörelerin ortalama kil miktarı \%32.9 olarak hesaplanmıştır. Tüm toprak örneklerinden elde edilen değerler incelendiğinde en düşük ve en yüksek kil miktarı \%13.8 ve \%59.9 olarak yine Baskil yöresinde hesaplanmıştır. Ağın yöresindeki ortalama kil miktarı yüzdesi farklı olarak Keban yöresine göre anlamlı düzeyde yüksek çıkmıştır (Çizelge 4). Silt yüzdesi açısından değerlendirildiğinde yöreler arasında herhangi bir anlamlı farklııık bulunamamıştır. Çalışma alanlarındaki tüm örneklerdeki silt değerleri incelendiğinde en düşük silt miktarı \%13.2 ile Sivrice yöresinde belirlenirken en yüksek değer ise Merkez yöresinde (\%32.9) belirlenmiştir (Çizelge 4). Ağın yöresindeki toprak tekstürü "killi", Merkez yöresi "killi tın" olarak çıkarken, Keban, Sivrice ve Baskil yörelerindeki tekstür yapısı "kumlu killi tın" olarak belirlenmiştir. Bu sonuçlar göstermektedir ki badem ağacı killi toprakları da içine alacak şekilde geniş bir tekstür yelpazesi içeresinde yetişebilmektedir. Ayrıca belirtmek gerekir ki bu kapsayış Ağın yöresinde olduğu gibi uygun ekolojik koşulların (iklim ve topografya) bulunduğu alanlar için söz konusu olabilir. Diğer bir ifadeyle; toprak türü, yağış miktarı ve eğim arasındaki etkileşim bu elverişli koşulun (havalanma ve geçirgenlik) oluşumunda etkili role sahiptir. Toprak örnekleri derinlik kademeleri açısından değerlendirildiğinde, bütün derinlik kademelerindeki kum, silt ve kil oranları benzerlik göstermiştir. Kum oranları (\%) 43.8 (0-30cm), 46.3 (30-60 $\mathrm{cm}), 47(60-90 \mathrm{~cm})$, ve kil oranları $(\%)$ ise $33.4(0-30 \mathrm{~cm})$, $32.6(30-60 \mathrm{~cm}), 32.6(60-90 \mathrm{~cm})$ olarak belirlenmiştir. 
Çizelge 4. Toprak örneklerinin fiziksel ve kimyasal özelliklerinin mevcut durumu ve yörelere (Keban, Merkez, Sivrice, Ağın, Baskil) göre değişimi.

\begin{tabular}{|c|c|c|c|c|c|c|c|}
\hline \multirow[t]{2}{*}{ Toprak Parametreleri } & \multicolumn{5}{|c|}{ Çalışma Yöreleri } & \multirow[t]{2}{*}{ Genel Ortalama } & \multirow{2}{*}{$\begin{array}{l}\text { Önem düzeyi } \\
(P)\end{array}$} \\
\hline & Keban & Merkez & Sivrice & Ağın & Baskil & & \\
\hline Kum (\%) & $\begin{array}{l}\text { k51.0a } \pm 3.1 \\
(38.1-70.0)\end{array}$ & $\begin{array}{l}43.0 \mathrm{ab} \pm 3.1 \\
(27.2-57.3)\end{array}$ & $\begin{array}{l}50.9 a \pm 2.9 \\
(33.3-60.2)\end{array}$ & $\begin{array}{l}35.5 b \pm 3.9 \\
(22.0-59.5)\end{array}$ & $\begin{array}{l}49.1 \mathrm{ab} \pm 4.8 \\
(21.4-65.8)\end{array}$ & $\begin{array}{l}45.7 \pm 1.8 \\
(21.4-70.0)\end{array}$ & 0.019 \\
\hline Silt (\%) & $\begin{array}{l}21.4 \mathrm{a} \pm 1.1 \\
(15.2-25.0)\end{array}$ & $\begin{array}{l}23.2 \mathrm{a} \pm 1.6 \\
(15.8-32.9)\end{array}$ & $\begin{array}{l}20.4 a \pm 2.0 \\
(13.2-30.9)\end{array}$ & $\begin{array}{l}22.2 \mathrm{a} \pm 1.8 \\
(14.3-29.4)\end{array}$ & $\begin{array}{l}19.2 \mathrm{a} \pm 0.7 \\
(15.5-22.7)\end{array}$ & $\begin{array}{l}21.4 \pm 0.07 \\
(13.2-32.9)\end{array}$ & 0.377 \\
\hline Tuz (\%) & $\begin{array}{l}0.13 a \pm 0.01 \\
(0.10-0.19)\end{array}$ & $\begin{array}{l}0.13 a \pm 0.01 \\
(0.08-0.17)\end{array}$ & $\begin{array}{l}0.08 b \pm 0.01 \\
(0.05-0.12)\end{array}$ & $\begin{array}{l}0.15 a \pm 0.01 \\
(0.11-0.19)\end{array}$ & $\begin{array}{l}0.13 a \pm 0.01 \\
(0.10-0.18)\end{array}$ & $\begin{array}{l}0.13 \pm 0.01 \\
(0.05-0.19)\end{array}$ & 0.000 \\
\hline Kireç (\%) & $\begin{array}{l}36.4 a \pm 6.1 \\
(15.4-68.9)\end{array}$ & $\begin{array}{l}22.8 a b \pm 5.4 \\
(0.8-51.7)\end{array}$ & $\begin{array}{l}3.1 c \pm 1.2 \\
(0.8-10.9)\end{array}$ & $\begin{array}{l}20.1 a b c \pm 2.5 \\
(13.5-36.9)\end{array}$ & $\begin{array}{l}15.8 b c \pm 3.6 \\
(3.0-39.6)\end{array}$ & $\begin{array}{l}19.8 \pm 2.4 \\
(0.8-68.9)\end{array}$ & 0.000 \\
\hline Organik madde (\%) & $\begin{array}{l}1.07 a \pm 0.14 \\
(0.51-1.64)\end{array}$ & $\begin{array}{l}1.28 a \pm 0.14 \\
(0.76-2.27)\end{array}$ & $\begin{array}{l}0.96 a \pm 0.11 \\
(0.46-1.53)\end{array}$ & $\begin{array}{l}1.11 a \pm 0.12 \\
(0.68-1.62)\end{array}$ & $\begin{array}{l}1.08 a \pm 0.22 \\
(0.51-2.39)\end{array}$ & $\begin{array}{l}1.11 \pm 0.07 \\
(0.46-2.39)\end{array}$ & 0.645 \\
\hline Kalsiyum (mg kg-1) & $\begin{array}{l}45921 a b \pm 3212 \\
(34340-65389)\end{array}$ & $\begin{array}{l}53315 a \pm 2844 \\
(34521-66022)\end{array}$ & $\begin{array}{l}36155 b \pm 6029 \\
(15500-63578)\end{array}$ & $\begin{array}{l}60013 a \pm 5599 \\
(39124-82821)\end{array}$ & $\begin{array}{l}57979 a \pm 2524 \\
(52641-75520)\end{array}$ & $\begin{array}{l}50841 \pm 2167 \\
(15500-82821)\end{array}$ & 0.002 \\
\hline Magnezyum (mg kg-1) & $\begin{array}{l}3681 a \pm 882 \\
(1264-8390)\end{array}$ & $\begin{array}{l}6994 b c \pm 594 \\
(2305-8571)\end{array}$ & $\begin{array}{l}6260 a b c \pm 917 \\
(2645-8694)\end{array}$ & $\begin{array}{l}8156 c \pm 139 \\
(7176-8603)\end{array}$ & $\begin{array}{l}4916 a b \pm 1071 \\
(928-8366)\end{array}$ & $\begin{array}{l}6064 \pm 400 \\
(928-8694)\end{array}$ & 0.002 \\
\hline Demir $\left(\mathrm{mg} \mathrm{kg}^{-1}\right)$ & $\begin{array}{l}2.97 a \pm 0.20 \\
(2.20-3.73)\end{array}$ & $\begin{array}{l}3.86 a \pm 0.20 \\
(3.10-5.17)\end{array}$ & $\begin{array}{l}4.39 a b \pm 0.37 \\
(3.57-6.17)\end{array}$ & $\begin{array}{l}5.70 b \pm 0.70 \\
(3.43-8.13)\end{array}$ & $\begin{array}{l}3.89 a \pm 0.08 \\
(3.73-4.53)\end{array}$ & $\begin{array}{l}4.14 \pm 0.20 \\
(2.20-8.13)\end{array}$ & 0.000 \\
\hline Mangan (mg kg-1) & $\begin{array}{l}1.65 a \pm 0.21 \\
(0.43-2.53)\end{array}$ & $\begin{array}{l}2.01 a \pm 0.16 \\
(1.23-2.97)\end{array}$ & $\begin{array}{l}1.45 a \pm 0.10 \\
(1.13-2.10)\end{array}$ & $\begin{array}{l}1.58 \mathrm{a} \pm 0.13 \\
(1.27-2.40)\end{array}$ & $\begin{array}{l}0.79 \mathrm{~b} \pm 0.06 \\
(0.60-1.17)\end{array}$ & $\begin{array}{l}1.53 \pm 0.09 \\
(0.43-2.97)\end{array}$ & 0.000 \\
\hline Çinko (mg kg-1) & $\begin{array}{l}1.64 a b \pm 0.07 \\
(1.50-2.20)\end{array}$ & $\begin{array}{l}1.54 a \pm 0.02 \\
(1.47-1.63)\end{array}$ & $\begin{array}{l}1.97 b c \pm 0.12 \\
(1.47-2.23)\end{array}$ & $\begin{array}{l}1.81 \mathrm{ab} \pm 0.13 \\
(1.47-2.23)\end{array}$ & $\begin{array}{l}2.21 c \pm 0.01 \\
(2.20-2.27)\end{array}$ & $\begin{array}{l}1.82 \pm 0.05 \\
(1.47-2.27)\end{array}$ & 0.000 \\
\hline Bakır (mg kg-1) & $\begin{array}{l}0.52 a \pm 0.05 \\
(0.13-0.63)\end{array}$ & $\begin{array}{l}0.51 a \pm 0.09 \\
(0.10-1.00)\end{array}$ & $\begin{array}{l}0.81 \mathrm{~b} \pm 0.02 \\
(0.73-0.90)\end{array}$ & $\begin{array}{l}0.85 b \pm 0.02 \\
(0.73-0.93)\end{array}$ & $\begin{array}{l}0.77 b \pm 0.03 \\
(0.63-0.90)\end{array}$ & $\begin{array}{l}0.68 \pm 0.03 \\
(0.10-1.00)\end{array}$ & 0.000 \\
\hline
\end{tabular}

kVerilen çalışma bölgesindeki ilgili toprak parametresinin ortalama değeri. a,b,c İstatistiksel anlamda farklılı̆ı ifade eden harfler. ${ }^{ \pm}$Standard sapma. Parantez içeresindeki değerler en küçük ve en büyük değerleri ifade etmektedir.

\section{Toprak reaksiyonu $(\mathrm{pH})$}

Toprak asitliği toprağın kimyasal, fiziksel ve biyolojik özelliklerini etkileyerek bitki besin elementlerinin elverişliliği ve alımını etkileyen en önemli toprak faktörlerinden birisidir. Ortalama $\mathrm{pH}$ değerleri incelendiğinde en düşük ortalama Sivrice yöresinde (6.58) belirlenirken, en yüksek ortalama değer ise Keban yöresinde (7.99) tespit edilmiştir (Çizelge 4). Tüm yörelerin ortalama $\mathrm{pH}$ değeri 7.61 olarak belirlenmiştir. Çalışma alanlarındaki tüm örnek toprak profilleri incelendiğinde en düşük pH değeri 6.18 ile Sivrice yöresinde, en yüksek değer ise Merkez yöresinde (8.37) belirlenmiştir. Sivrice yöresindeki ortalama pH değeri farklı olarak diğer bütün yörelere göre anlamlı düzeyde düşük çıkmıştır (Çizelge 4). Sınır değerleri incelendiğinde Sivrice yöresi "hafif asit" (pH: 5.5- 6.5) grubuna girerken (Çizelge 3), diğer alanlar "hafif alkali" (pH:7.5-8.5) grubuna girmektedir. Analiz sonuçları değerlendirildiğinde Elazığ ili badem ağaçlarının daha çok

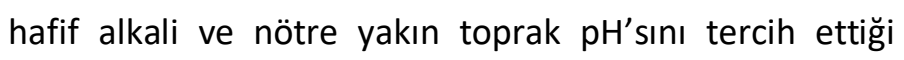
görülmüştür. Bitki türüne bağlı olarak kökler topraktaki besin maddelerini en iyi pH 6.5-7.5 arasında alabilmektedirler. Analize tabi tutulan toprak numunelerinin $\mathrm{pH}$ değerleri incelendiğinde, bitki besin elementlerinin topraktan alımı ve topraktaki mikroorganizma faaliyetleri açısından sıkıntı teşkil etmeyeceği düşünülmektedir. Fakat belirtmek gerekir ki; yüksek $\mathrm{pH}$ değerleri yüksek kireç oranının olduğu alanlarda bazı bitki besin elementlerinin ( $\mathrm{Mn}, \mathrm{Fe})$ alımında sorun oluşturabilir. Özellikle pH değerlerinin 7.5 ten yüksek olduğu alanlarda elementer kükürt, amonyum sülfat ve amonyum nitrat kullanılarak toprak alkaliliği düşürülebilir (Hızal 1984).

\section{Tuz}

Yöreler açısından ortalama tuz değerleri incelendiğinde en düşük ortalama Sivrice (\%0.08), en yüksek ortalama değer ise Ağın yöresinde (\%0.15) tespit edilmiştir 
(Çizelge 4). Tüm yöre topraklarının ortalama tuz içeriği \%0.13 olarak belirlenmiştir. Tüm örnek toprak profillerindeki tuz içeriği incelendiğinde en düşük \%0.05 ile Sivrice yöresinde belirlenirken en yüksek Keban ve Ağın yörelerinde (\%0.19) belirlenmiştir. Sivrice yöresindeki ortalama tuz içeriği anlamlı düzeyde farklılık oluşturarak diğer bütün yörelere göre düşük çıkmıştır (Çizelge 4). Sınır değerlerine göre değerlendirildiğinde bütün yörelerdeki topraklar "tuzsuz" sınıfına girmektedir (\%0-\%0.15; Çizelge 3).

\section{Toplam kireç}

Topraklardaki kireç oranı toprak $\mathrm{pH}^{\prime}$ sını ve bitki besin maddelerinin çözünürlüklerinde etkili olduğu için bitkilerin beslenmesi için önem taşır. Diğer yandan kireçli topraklarda yüksek düzeydeki kalsiyumun, bitkiler tarafından $\mathrm{K}^{+}$ve $\mathrm{Mg}^{+2}$ alımını azaltabilmekte ve noksanlığa neden olabilmektedir. Ayrıca $\mathrm{Fe}, \mathrm{Mn}, \mathrm{Cu}, \mathrm{Zn}$ gibi elementlerin alımında da sorun oluşturabilmektedir (Weil ve Brady 2016). Organik madde ilavesiyle toprakların kireç yüzdesi azaltılabilir. Çalışmadaki ortalama kireç değerleri incelendiğinde en düşük ortalama Sivrice yöresinde (\%3.1), en yüksek ortalama ise Keban yöresinde (\%36.4) tespit edilmiştir (Çizelge 4). Tüm yöre topraklarının ortalama kireç içeriği \%19.8 olarak belirlenmiştir. Çalışma alanlarındaki tüm örnek toprak profillerindeki kireç değerleri incelendiğinde en düşük kireç değeri \%0.8 ile Merkez ve Sivrice yörelerinde, en yüksek Keban yöresinde (\%68.9) olarak çok geniş bir aralıkta belirlenmiştir. Keban yöresindeki ortalama kireç yüzdesi anlamlı düzeyde farklılık oluşturmuş olup Baskil ve Sivrice yörelerine göre yüksek çıkmıştır (Çizelge 4). Benzer şekilde Merkez'deki kireç yüzdesi de Sivrice yöresine göre anlamlı düzeyde yüksek çıkmıştır. Kireç bakımından "sınır değerleri" incelendiğinde Sivrice yöresi "kireçli" (\%1-5), Baskil, Ağın ve Merkez yöreleri "fazla kireçli" (\%15-25), ve Keban ise "çok fazla kireçli" (>\%25) toprak sınıfına girmektedir (Çizelge 3). Genel olarak değerlendirdiğimizde çalışma alanlarındaki toprakların büyük bir kısmı "fazla kireçli" ve "çok fazla kireçli" topraklar sınıfına girmektedir.

\section{Organik madde (OM)}

Toprağın fiziksel, kimyasal, biyolojik niteliklerini düzenlenmesi; erozyonu engellemesi, ürün miktar ve kalitesini artırması nedeniyle $\mathrm{OM}$ en önemli toprak bileşenlerinden biri olma özelliğindedir. Toprak OM kapsamı organik üretimde bitkilerinin ihtiyacı olan azotun sağlanması açısından çok önemli bir kıstas olarak değerlendirilmektedir. Ancak genellikle toprak OM kapsamı ülkemiz iklim koşullarından ve toprakların çok uzun süredir işlenmekte olmasından dolayı düşüktür (<\%2). Bu çalışmada yöreler arasında OM yüzdesi bakımından farklııı anlamlı düzeyde çıkmamıştır (Çizelge 4). Ortalama OM miktarları incelendiğinde en düşük ortalama Sivrice yöresinde (\%0.96), en yüksek ortalama ise Merkez yöresinde (\%1.28) çıkmıştır. Tüm yörelerin ortalama OM içeriği \%1.11 olarak belirlenmiştir. Tüm toprak profillerindeki OM miktarları değerlendirildiğinde en düşük değer \%0.46 ile Sivrice'de, en yüksek değer ise Baskil yöresinde (\%2.39) belirlenmiştir. Organik maddece \% 1'in altındaki topraklar "çok az" toprak sınıf değerine girmektedir (Çizelge 3). Analiz sonuçları değerlendirildiğinde toprakların OM içeriği bakımından bütün bölgelerde yetersiz (fakir) olduğu sonucu ortaya çıkmıştır. Hayvan gübresi uygulaması organik madde miktarını artırmak için en etkin yöntemlerden biridir. Organik madde oranları toprak profil derinliklerine göre değerlendirildiğinde, $0-30 \mathrm{~cm}$ derinliğindeki OM içeriğinin (\%0.86) "çok az", 30-60 cm (\%1.06) ve 60-90 cm (\%1.41) derinliklerinde ise "az" toprak sınıflarında olduğu belirlenmiştir.

\section{Makro Besin Elementleri}

\section{Fosfor (P)}

Yöreler açısından ortalama yarayışlı $P$ değerleri incelendiğinde en düşük ortalama Merkez yöresinde (23.6 $\mathrm{mg} \mathrm{kg}^{-1}$ ), en yüksek ortalama Sivrice ise yöresinde (95.3 mg kg ${ }^{-1}$ ) çıkmıştır (Çizelge 4). Tüm yörelerin ortalama $\mathrm{P}$ değeri $47.5 \mathrm{mg} \mathrm{kg}^{-1}$ olarak belirlenmiştir. Tüm toprak profillerindeki $P$ değerleri incelendiğinde en düşük değer $3.1 \mathrm{mg} \mathrm{kg}^{-1}$ ile Merkez yöresinde, en yüksek değer ise Sivrice yöresinde (201.2 $\mathrm{mg} \mathrm{kg}^{-1}$ ) belirlenmiştir. Sivrice yöresi topraklarının ortalama $\mathrm{P}$ miktarı anlamlı farklılık oluşturarak Merkez ve Ağın yörelerine göre yüksek çıkmıştır (Çizelge 4). Fosfor için "sınır değerlerine" bakıldığında; toprakların yarayışlı P içerikleri Merkez yöresinde "yeterli" (8-25 mg kg $\left.{ }^{-1}\right)$, Ağın, Keban ve Baskil yörelerinde "fazla" (25-80 $\left.\mathrm{mg} \mathrm{kg}^{-1}\right)$, ve sivrice 
yöresinde "çok fazla" (>80 mg kg-1) olarak tespit edilmiştir (Çizelge 3). Genel olarak değerlendirdiğimizde Çalışılan yöre toprakları yarayışlı $P$ içeriği açısından badem yetiştiriciliği için elverişlidir.

\section{Potasyum (K)}

Tüm yöre topraklarının yarayışlı K miktarları arasındaki farklıık anlamlı düzeyde çıkmamıştır (Çizelge 4). Ortalama $\mathrm{K}$ değerleri incelendiğinde en düşük ortalama Baskil yöresinde (222 $\mathrm{mg} \mathrm{kg}^{-1}$ ) belirlenirken, en yüksek ortalama Ağın yöresinde $\left(353 \mathrm{mg} \mathrm{kg}^{-1}\right.$ ) çıkmıştır. Tüm yörelerin ortalama alınabilir K değeri $266 \mathrm{mg} \mathrm{kg}^{-1}$ olarak belirlenmiştir. Alınan tüm toprak profillerindeki $\mathrm{K}$ değerleri incelendiğinde en düşük değer $58 \mathrm{mg} \mathrm{kg}^{-1}$ ile Merkez'de, en yüksek değer ise Baskil yöresinde (588 mg $\mathrm{kg}^{-1}$ ) belirlenmiştir. Yarayışlı K "sınır değerleri" incelendiğinde Sivrice, Baskil, Merkez ve Keban yörelerinin "yeterli" (109-288 mg kg-1), Ağın yöresinin "fazla" (288-998 $\mathrm{mg} \mathrm{kg}^{-1}$ ) sınıfına girdiği tespit edilmiştir (Çizelge 3). Bu sınıflamaya göre çalışma alanı toprakları badem yetiştirilmesi için potasyumca yeterli düzeyde olduğu tespit edilmiştir. Yarayışı potasyum miktarları toprak profil derinliklerine göre değerlendirildiğinde, 0 $30 \mathrm{~cm}$ derinliğindeki potasyum miktarının $\left(351 \mathrm{mg} \mathrm{kg}^{-1}\right)$ "fazla", 30-60 cm (245 mg kg-1) ve 60-90 cm (201 $\left.\mathrm{mgkg}^{-1}\right)$ derinliklerinde ise "yeterli" toprak sınıfında olduğu belirlenmiştir.

\section{Kalsiyum (Ca)}

Faydalı Ca değerleri incelendiğinde en düşük ortalama Sivrice yöresinde $\left(36155 \mathrm{mg} \mathrm{kg}^{-1}\right)$, en yüksek ortalama ise Ağın yöresinde $\left(60013 \mathrm{mg} \mathrm{kg}^{-1}\right)$ çıkmıştır (Çizelge 4). Tüm yörelerin ortalama $\mathrm{Ca}$ değeri $50841 \mathrm{mg} \mathrm{kg}$ olarak belirlenmiştir. Tüm örnek profillerdeki $\mathrm{Ca}$ değerleri incelendiğinde en düşük değer $15500 \mathrm{mg} \mathrm{kg}^{-1}$ ile Sivrice yöresinde belirlenirken en yüksek değer ise Ağın yöresinde (82821 mg kg-1) belirlenmiştir. Sivrice yöresi topraklarındaki ortalama Ca miktarı Merkez, Ağın ve Baskil yörelerinin ortalama değerlerine göre anlamlı düzeyde en düşük çıkmıştır (Çizelge 4). "Sınır değerleri" açısından incelendiğinde tüm yöre toprakları "çok fazla" (>10000 mg kg ${ }^{-1}$ ) (Çizelge 3) kalsiyum sınır değeri içeresinde yer almaktadır. Çalışma sahası topraklarının Ca içeriği açısından iyi seviyede olduğu tespit edilmiştir.

\section{Magnezyum (Mg)}

Magnezyum değerleri incelendiğinde en düşük Keban yöresinde (3681 $\mathrm{mg} \mathrm{kg}^{-1}$ ), en yüksek ortalama Ağın yöresinde (8156 mg kg-1) çıkmıştır (Çizelge 4). Tüm yörelerin ortalama Mg değerleri $6064 \mathrm{mg} \mathrm{kg}^{-1}$ olarak belirlenmiştir. Tüm toprak profillerindeki $\mathrm{Mg}$ değerleri incelendiğinde en düşük değer $928 \mathrm{mg} \mathrm{kg}^{-1}$ ile Baskil yöresinde, en yüksek değer ise Sivrice yöresinde (8694 $\mathrm{mg} \mathrm{kg}^{-1}$ ) belirlenmiştir. Ağın yöresi topraklarındaki ortalama Mg miktarı, Keban ve Baskil yörelerinin ortalama değerlerine göre anlamlı düzeyde en yüksek çıkmıştır (Çizelge 4). Keban ve Merkez yöresi topraklarında da $\mathrm{Mg}$ değeri bakımından farklılık anlamlı düzeyde çıkmıştır. Bu sonuçlara göre, sınır değerlerine bakıldığında bütün yörelerin $\mathrm{Mg}$ içeriğinin $1500 \mathrm{mg} \mathrm{kg}{ }^{-1}$ den yüksek olması (Çizelge 3) bu toprakların $\mathrm{Mg}$ bakımından "çok fazla" toprak sınıfına girdiğini göstermektedir. Magnezyum fazlalığı ağaçların kök gelişimini ve potasyum alımını olumsuz etkileyebilmektedir (Aktaş ve Ateş 1998).

\section{Mikro Besin Elementleri}

\section{Demir (Fe)}

Topraklardaki ortalama $\mathrm{Fe}$ içeriği incelendiğinde en düşük ortalama değer Keban yöresinde $\left(2.97 \mathrm{mg} \mathrm{kg}^{-1}\right)$, en yüksek değer ise Ağın yöresinde $\left(5.70 \mathrm{mg} \mathrm{kg}^{-1}\right)$ çıkmıştır (Çizelge 4). Tüm yörelerdeki toprakların ortalama $\mathrm{Fe}$ içeriği $4.14 \mathrm{mg} \mathrm{kg}^{-1}$ olarak belirlenmiştir. Tüm toprak profillerinin Fe miktarı incelendiğinde en düşük değer $2.20 \mathrm{mg} \mathrm{kg}^{-1}$ ile Keban yöresinde, en yüksek değer ise Ağın yöresinde $\left(8.13 \mathrm{mg} \mathrm{kg}^{-1}\right)$ belirlenmiştir. Ağın yöresi topraklarının ortalama Fe miktarı, Keban, Merkez ve Baskil yörelerinin ortalama Fe değerlerinden farklı olarak anlamlı düzeyde yüksek çıkmıştır (Çizelge 4). Bu sonuçlara göre "sınır değerleri" incelendiğinde, Ağın yöresinin faydalı Fe içeriği bakımından "fazla" (>4.5 mg $\left.\mathrm{kg}^{-1}\right)$, diğer yörelerin ise "orta" (2.5-4.5 mg kg-1) sınıfta yer aldığı tespit edilmiştir (Çizelge 3). Bu sonuçları göre Elazığ ili ve bölge toraklarının Fe içeriğinin badem yetiştiriciliği için yeterli olduğu kanısına varılmıştır.

\section{Mangan (Mn)}

Ortalama $\mathrm{Mn}$ içeriği incelendiğinde en düşük Baskil yöresinde $\left(0.79 \mathrm{mg} \mathrm{kg}^{-1}\right)$, en yüksek ortalama ise 
Merkez'de (2.01 mg kg${ }^{-1}$ ) tespit edilmiştir (Çizelge 4). Tüm yörelerdeki toprakların ortalama Mn değeri $1.53 \mathrm{mg}$ $\mathrm{kg}^{-1}$ olarak belirlenmiştir. Tüm toprak profillerinin $\mathrm{Mn}$ değerleri incelendiğinde en düşük değer $0.43 \mathrm{mg} \mathrm{kg}^{-1}$ ile Keban yöresinde belirlenirken en yüksek değer ise Merkez'de $\left(2.97 \mathrm{mg} \mathrm{kg}^{-1}\right.$ ) belirlenmiştir. Baskil yöresi topraklarındaki ortalama $\mathrm{Mn}$ miktarı anlamlı düzeyde farklı olarak, diğer bütün yörelerin ortalama $\mathrm{Mn}$ değerlerine göre en düşük çıkmıştır (Çizelge 4). Bu sonuçlara göre, mangan için "sınır değerleri" incelendiğinde bütün yörelerdeki ortalama $\mathrm{Mn}$ değerlerinin $4 \mathrm{mg} \mathrm{kg}^{-1}$ in altında olması nedeni ile badem yetiştirilen bu toprakların $\mathrm{Mn}$ bakımından yetersiz ("çok az") (Çizelge 3) sınıfında olduğu tespit edilmiştir. Mangan noksanlığı yörede badem üretimi sınırlayıcı verimini etkileyici bir faktör olarak ortaya çıkmıştır. Elde edilen bulgular ışığında, araştırma sahamıza ait toprakların hafif alkali reaksiyon göstermeleri de dikkate alındığında; özellikle manganın yarayışlılığını artıııcı (Sameni ve Kasraian 2004) bir özelliğe sahip olan elementel kükürdün gübreleme programına katılması yararlı olacaktır.

\section{Çinko (Zn)}

Ortalama $\mathrm{Zn}$ içeriği incelendiğinde en düşük Merkez yöresinde (1.54 mg kg-1) belirlenirken, en yüksek ortalama Baskil yöresinde $\left(2.21 \mathrm{mg} \mathrm{kg} \mathrm{kg}^{-1}\right)$ çıkmıştır (Çizelge 4). Tüm yörelerdeki toprakların ortalama $\mathrm{Zn}$ değeri $1.82 \mathrm{mg} \mathrm{kg}^{-1}$ olarak belirlenmiştir. Tüm örneklerin çinko verileri incelendiğinde en düşük değer $1.47 \mathrm{mg} \mathrm{kg}^{-1}$ ile Sivrice yöresinde, en yüksek değer ise Baskil yöresinde $\left(2.27 \mathrm{mg} \mathrm{kg}^{-1}\right)$ belirlenmiştir. Sivrice yöresi hariç, Baskil yöresi topraklarının ortalama Zn miktarı anlamlı düzeyde farklı olarak, diğer yörelerin ortalama $\mathrm{Zn}$ değerlerine göre en fazla çıkmıştır (Çizelge 4). Ortalama Zn değerleri Sivrice ve Merkez bölge toprakları içinde anlamlı farklık oluşturmuştur. Bu sonuçlara göre, Zn bakımından "sınıf değerleri" incelendiğinde bütün yörelerin ortalama değerlerinin 0.7-2.4 $\mathrm{mg} \mathrm{kg}^{-1}$ aralığında olması nedeni ile badem yetiştirilen bu toprakların çinko bakımından "yeterli" toprak sınıfı içeresinde olduğu belirlenmiştir (Çizelge 3).

\section{Bakır (Cu)}

Toprakların ortalama yarayışlı $\mathrm{Cu}$ içeriği incelendiğinde en düşük değerin Merkez'de $\left(0.51 \mathrm{mg} \mathrm{kg}^{-1}\right)$, en yüksek ortalama değerin ise Ağın yöresinde (0.85 mg kg-1) olduğu tespit edilmiştir (Çizelge 4). Tüm yörelerdeki toprakların ortalama $\mathrm{Cu}$ değeri $0.68 \mathrm{mg} \mathrm{kg} \mathrm{kg}^{-1}$ olarak belirlenmiştir. Tüm toprak profillerinin $\mathrm{Cu}$ değerleri incelendiğinde en düşük ve en yüksek değerlerin $0.10 \mathrm{mg}$ $\mathrm{kg}^{-1}$ ve $1 \mathrm{mg} \mathrm{kg}^{-1}$ olarak Merkez'de olduğu tespit edilmiştir. Ortalama $\mathrm{Cu}$ değerleri için anlamlı farklııklar Sivrice, Ağın ve Baskil yöreleri ile Keban ve Merkez yöreleri arasında tespit edilmiştir (Çizelge 4). Bu sonuçlara göre, yarayışı Cu bakımından "sınır değerleri" incelendiğinde tüm bölge topraklarının "yeterli" (orta; $>0,2 \mathrm{mg} \mathrm{kg}^{-1}$ ) sınıfında olduğu tespit edilmiştir (Çizelge 3 ).

\section{SONUÇ VE ÖNERILER}

Bu çalışmada badem ağacının yetiştirilmekte olduğu Elazığ iline bağlı Merkez, Sivrice, Ağın, Baskil ve Keban yörelerindeki toprakların fiziksel ve kimyasal yapısı belirlenerek badem yetiştiriciliğine uygunluğu ve bunun için yapılması gerekenler konusunda önerilerde bulunulmuştur. Elazığ yöreleri içeresinde Ağın ve Merkez'deki toprak türlerinin "killi" ve "killi balçık", Keban, Sivrice ve Baskil'de ise "kumlu killi tın olduğu tespit edilmiştir. Sivrice yöresi hariç (hafif asit), diğer bütün yörelerdeki toprak pH sınıfının "hafif alkali" olduğu tespit edilmiştir. Tuz içerikleri açısından bölge toprakları "tuzsuz" sınıfı içerisinde yer alırken, kireç bakımından genel olarak "fazla kireçli" (merkez, Ağın ve Baskil) ve "çok fazla kireçli" (Keban) sınıflarında yer almaktadırlar. Bütün yöre toprakları organik madde sınır değerlerine göre "çok az" topraklar sınıfındadır. Yarayışlı fosfor içeriği bakımından bölge toprakları genellikle "fazla" (Keban, Ağın ve Baskil) ve "çok fazla" (Sivrice) sınır değeri kategorisindedir. Bütün yöre toprakları yarayışlı potasyum açısından "yeterli", Kalsiyum ve Magnezyum açısından ise "çok fazla" sınır değeri kategorisinde yer aldığı tespit edilmiştir. Demir bakımından bölge topraklarının "orta", Mangan için "çok $a z "$ sınır değerleri içerisinde yer aldığı tespit edilmiştir. Son olarak çinko ve bakır açısından ise "yeterli" sınıf değerlerinde olduğu tespit edilmiştir. 
Elâzığ ili toprakları badem yetiştiriciliği açısından genel olarak tekstür, pH, tuzluluk, yarayışlı potasyum, magnezyum, demir, çinko ve bakır miktarları için önemli ölçüde bir sorun teşkil etmemektedir. Kireç, yarayışlı fosfor, kalsiyum ve magnezyum miktarlarının çok fazla seviyede bulunduğu bölge topraklarındaki en önemli noksanlığın organik madde ile manganda yaşandığı tespit edilmiştir. Genel anlamda besin maddelerinin yeterli, toprak yapısının da bademin istemediği ağır killi ve drenajı yetersiz topraklar olmadığı analiz sonuçlarında ve incelemelerde ortaya çıkmıştır. Badem ağacının yetişme koşulları için çok önemli olumsuz bir durum teşkil etmese de verimlilik (meyve üretimi) açısından düşünüldüğünde besin maddeleri takviyesi yapmak, toprağı gübrelemek ve organik madde içeriğini artırarak kireç içeriğini azaltmak bademin yetişme koşullarını daha elverişli duruma getirilebilir.

\section{AÇIKLAMA}

Bu çalışma Tuğçe Dilşad AKGÜN'ün “Elâzığ Yöresinde Yetişen Badem Ağaçlarının Yetişme Yeri Özelliklerinin Belirlenmesi" isimli yüksek lisans tez verilerinden üretilmiştir.

\section{REFERENCES}

\section{KAYNAKLAR}

Akçalı E, Uzun A (2016) Erciyes dağı eteklerinde seçilen badem (Prunus amygdalus L) tiplerinde bazı fenolojik ve pomolojik özelliklerin belirlenmesi. Akademik Ziraat Dergisi 5(2): 63-68.

Akçay ME, Tosun i (2005) Bazı geç çiçek açan yabancı badem çeşitlerinin Yalova ekolojik koşullarındaki gelişme ve verim davranışları. Atatürk Üniversitesi Ziraat Fakültesi Dergisi, 36(1): 15.

Aktaş M, Ateş M (1998) Bitkilerde Beslenme Bozuklukları, Nedenleri ve Tanınmaları. Engin Yayınevi, Ankara. $247 \mathrm{~s}$.

Alkan G, Seferoğlu HG (2014) Bazı badem çeşitlerinin Aydın ekolojisindeki fenolojik ve morfolojik özellikleri. Meyvecilik Araştırma İstasyonu Müdürlüğü 1(2): 38-44.

Altun L, (1995) Maçka (Trabzon) orman işletmesi orman üstü serisinde orman yetişme ortamı birimlerinin ayrılması ve haritalanması üzerine araştırmalar, Doktora Tezi, KTÜ Fen Bilimleri Enstitüsü, Trabzon.

Anonim (1981) Descriptor list for Almond (Prunus amygdalus). Revise d. IBPGR excutive secretariat Roma, Italy. (Editör R.Gülcan).

Bingham FT (1949) Soil test for phosphate. California Agriculture 3(7):11-14.

Bouyoucos, G.J.,1951. A recalibration of the hydrometer method for making mechanical analysis of soil. Argon. Jour. 43: 434-438.

Çağlar KÖ (1949). Toprak Bilgisi, A.Ü. Ziraat Fakültesi yayınları, Yayın No:10, Ankara.
Chapman HD, Pratt PF (1961) Methods of analysis for soils, plants and waters. University of California, Division of Agricultural Science, Berkeley, California.

De Martonne E (1942) Nouvelle Carte Modiale de l'indice d'aridit é. Annaes de Géographie, 51: 242- 250.

Eldoğan Ü, Şahan A, Çoban N (2014) Badem yetiştiriciliğinin dünya ve Türkiye deki mevcut ekonomik durumu. Türk Tarım ve Doğa Bilimleri Dergisi Özel sayı, 2: 1379-1386.

Erinç S (1984) Klimatoloji ve Metodları. İstanbul: Deniz Bilimleri ve Coğrafya Enstitüsü Yayınları.

Evliya H (1960) Kültür Bitkilerinin Beslenmesi. Ankara Üniversitesi Ziraat Fak. Yay. No: 36, $656 \mathrm{~s}$.

FAO (1990) Micronutrient. Assessment at the Country Level: An International Study. FAO Soil Bulletin by Mikko Sillanpaa. Rome.

Gülçur F (1974) Toprağın fiziksel ve kimyasal analiz metodları. İstanbul Üniversitesi Orman Fakültesi Yayınları. Yayın No:1970 O.F. Yayın No:201 Kutulmuş Matbaası. İstanbul. XXIV+222 s.

Gülsoy E, Balta F (2014) Aydın ili Yenipazar, Bozdoğan ve Karacasu ilçeleri badem (Prunus amygdalus Batch) seleksiyonu: Pomolojik özellikler. Akademik Ziraat Dergisi 3(2): 61-68.

Gülsoy E, Ertürk YE, Şimşek M (2016) Türkiye lokal badem (Prunus amygdalus L.) seleksiyon çalışmaları. Yüzüncü Yıl Üniversitesi Tarım Bilimleri Dergisi 26(1): 126-134.

Hızal A (1984) Ezine orman fidanlığı topraklarında ph' nın sülfirik asit yöntemiyle düşürülmesi olanakları. İstanbul Üniversitesi, Orman Fakültesi Dergisi, Seri A. Cilt 34, Sayı 1.

Irmak A (1954) Arazide ve laboratuvarda toprağın araştırılması metotları. İstanbul Üniversitesi Yayın No: 599 O.F. Yayın No:27. İstanbul Halk Matbaası, $150 \mathrm{~s}$.

Kacar B (2009) Toprak Analizleri. Nobel Yayın dağıtım. Genişletilmiş 2. Baskı. 467 Sayfa.

Kester DE, Gradziel TM (1996) Almonds. Fruit Breeding. In J. Janick and J.N.Moore (Eds). John Wiley\&Sons,Inc. ISBN0-471-126691,Volume III,1240.

Lindsay WL, Norvell WA (1978) Development of a DTPA test for zinc, Iron, manganese and copper. J. Soil Science. Am., 42: 421-428.

Naçan G (1986) Güneydoğu Anadolu Bölgesinde zarar yapan böcek türleri, önlemlerinin tanınması, yayılışları ve ekonomik önlemleri üzerinde araştırmalar. T.C. Tarım Orman ve Köy İşleri Bakanlığı. Diyarbakır Zirai Araştırma Enstitüsü Müdürlüğü Araştırma Serisi. No:5,Ankara 77. s.

Özbek S (1971) Bağ-Bahçe Bitkileri Islahı. Atatürk Üniversitesi Ziraat Fakültesi Yayınları No: 419, Ankara, $386 \mathrm{~s}$.

Özbek S (1978) Özel Meyvecilik. Çukurova Üniversitesi Ziraat Fakültesi Yayınları: 128. Ders Kitabı:11 Adana.

Özçağıran R, Ünal A, Özeker E, İsfendiyaroğlu M (2005) Ilıman iklim meyve türleri, sert kabuklu meyveler Cilt-III. Ege Üniversitesi Yayınları, Ziraat Fakültesi Yayın No:566, İzmir.

Phychorraphis J (1977) Tropical crops, fruits and nuts. The Royal Horticultural Society Dictionary of Gardening. 1977; 3: 217-218.

Richards LA (1954) Diagnosis and improvement of saline and alkali soils. US Salinity Lab., (Ed.), United States Department of Agriculture Handbook, 60:94 California, USA.

Rugini E, Monastra F (2003). Temperate Fruits. In S.K. Mitra, D.S. Rathora and T.K. Bose (Eds), Display Printers (P) LTD. India, ISBN 81-900171-1-X, Volume II, 344-414 s.

Sameni AM, Kasraian A (2004) effect of agricultural sulfur on characteristics of different calcareous soils from dry regions of Iran. I. Disintegration rate of agricultural sulfur and its effects on chemical properties of the soils. Communications in Soil Science and Plant Analysis 35: 1219-1234.

Şimşek M, Çömlekçioğlu S, Osmanoğlu A (2010) Çüngüş ilçesinde doğal olarak yetişen bademlerin seleksiyonu üzerinde bir 
araştırma. Harran Üniversitesi Ziraat Fakültesi Dergisi 14(1): 3744.

Şimşek M, Gülsoy E (2017) Güney Doğu Anadolu Bölgesinin badem (Prunus amygdalus L.) potansiyeline genel bir bakış. Iğdır Üniversitesi Fen Bilimleri Enst. Dergisi 7(3): 19-29.

Soylu A (2003) Ilıman İklim Meyveleri II. Uludağ Üniversitesi Ziraat Fakültesi Ders Notları, Bursa, No:72.

Thornthwhite CV (1948) An aproach toward a rational classification of climate, Georg Rev. 38: 55-94.

USDA-NRCS (2011) Soil Survey Laboratory Information Manual.2011. Soil Survey Investigations Report No. 45. United States Department of Agriculture Natural Resources Conservation Service National Soil Survey Center Lincoln, Nebraska

Ülgen N, Yurtsever N (1974). Türkiye gübre ve gübreleme rehberi (3. Baskı). T.C. Tarım Orman Köyişleri Bakanlığı, Köy Hizmetleri Genel
Müdürlüğü, Toprak ve Gübre Araştırma Enstitüsü Müdürlüğü Yayınları, Genel Yayın No: 151, 182 s., Ankara.

Ülkümen L (1973) Bağ- bahçe ziraatı. Atatürk Üniversitesi Yayınları. No:75, Zir. Fakültesi Yayınları No:128. 404 s., Erzurum.

URL,1.,https://www.ogm.gov.tr/_layouts/OGM/OGMAramaSonuclari .aspx?k=badem\&cs=Bu\%20Site\&u=https\%3A\%2F\%2Fwww.ogm.g ov.tr\%2Fekutuphane.Erişim: 7.11.2018.

URL,2., http://www.tuik.gov.tr/PreÇizelge.do?alt id=1001. Erişim tarihi: 7.11.2018.

URL,3., http://web.firat.edu.tr/cografya/eg/dogal.html\#2.1.\%20Jeolojik\% 20Yap\%C4\%B1

URL,4., https://www.mgm.gov.tr/?il=Elazig Erişim Tarihi: 03.08.2018.

Weil RR, Brady NC (2016) The nature and properties of soils. 15th edition. Pearson Education, Columbus,USA. 